\title{
PENGARUH LIKUIDITAS, LEVERAGE, DAN KOMITE AUDIT TERHADAP AGRESIVITAS PAJAK
}

\author{
Agus Alifia Putri ${ }^{1 *}$, Rheny Afriana Hanif ${ }^{2}$ \\ ${ }^{123}$ Program Studi Akuntansi, Fakultas Ekonomi dan Bisnis, Universitas Riau, Pekanbaru \\ *Email: agus.alifiaputri9a@gmail.com
}

\begin{tabular}{l}
\hline Keywords \\
\hline Liquidity \\
Leverage, \\
Audit Committee, \\
Tax Aggressiveness \\
\hline Article Information \\
\hline Received: \\
2020-07-28 \\
Accepted: \\
2020-10-23 \\
Available online: \\
2020-11-29
\end{tabular}

\begin{abstract}
The aim of this study was to analyze the effect of liquidity, leverage, and audit committee on tax aggressiveness. Effective tax rate (ETR) used to measure tax aggressiveness. Population on this study is a manufacturing companies listed on the Indonesia Stock Exchange period 2016-2018. 74 companies were selected using the purposive sampling method. This study uses documentation data collection methods obtained from data tracking through electronic media such as annual report data and company financial statements that are sampled. Data processing techniques in this study use the method of multiple linear regression analysis with SPSS Version 25. The results of this study indicate that the liquidity and audit committee have negative effect on tax aggressiveness While leverage has a positive effect on tax aggressiveness.
\end{abstract}

\section{PENDAHULUAN}

Pajak memegang peranan penting dalam pelaksanaan perekonomian di Indonesia. Pajak yang merupakan kontribusi wajib orang pribadi atau badan yang bersifat memaksa masih menjadi sumber penerimaan terbesar bagi negara, hal ini dapat dilihat dari komposisi penerimaan perpajakan dalam Anggaran Pendapatan dan Belanja Negara (APBN) yang memiliki persentase mencapai $80 \%$ dari total penerimaan negara secara keseluruhan. Oleh karena itu, pemerintah selalu berupaya untuk mengoptimalkan penerimaan pajak agar dapat terus meningkat dan mencapai target yang telah ditetapkan.

Tujuan pemerintah dalam pengoptimalan pada sektor pajak guna membiayai penyelenggaraan kegiatan pemerintah untuk meningkatkan kesejahteraan masyarakat bertolak belakang dengan tujuan dari perusahaan sebagai wajib pajak. Perusahaan menginginkan pembayaran pajak seminimal mungkin agar memperoleh keuntungan yang lebih besar sehingga perusahaan dapat mensejahterakan pemilik dan melanjutkan kelangsungan hidup perusahaannya dari hasil keuntungan tersebut. Hal ini dikarenakan perusahaan menganggap 
bahwa pajak merupakan beban yang dapat mengurangi laba yang akan diterima perusahaan.

Berdasarkan data dari Direktorat Jenderal (Ditjen) Pajak Kementerian Keuangan (Kemenkeu) menunjukkan bahwa rasio pajak (tax ratio) Indonesia pada tahun 2018 berada di kisaran $11 \%$. Angka $11 \%$ tercatat sebagai yang terendah dibandingkan dengan negara-negara ASEAN lainnya. Data Organisation for Economic Co-operation and Development (OECD) pada tahun 2017 menunjukkan rasio pajak Malaysia berada di level 15\%, Singapura 13,6\%, dan Filipina 14,6\%. Rasio pajak Indonesia yang rendah mengindikasikan belum adanya pengoptimalan penerimaan pajak. Hal tersebut menimbulkan pertanyaan apakah pemungutan pajak yang dilakukan oleh pemerintah belum mampu berjalan secara maksimal, atau penetapan target yang ingin dicapai terlalu tinggi, ataukah dari sisi wajib pajaknya terdapat tindakan agresivitas pajak.

Peluang untuk melakukan tindakan agresivitas pajak muncul karena sistem perpajakan di Indonesia menggunakan self assessment system. Dalam hal ini, wajib pajak diberikan kewenangan melakukan kewajiban pajak mereka sendiri, mulai dari penghitungan hingga pelaporan pajaknya. Penggunaan sistem ini akan memotivasi wajib pajak untuk meminimalkan pembayaran pajak mereka, baik dengan melanggar hukum atau tidak melanggar hukum sehingga dimungkinkan wajib pajak akan menjadi agresif terhadap pajak. Tindakan agresivitas pajak perusahaan dimungkinkan akan terus terjadi mengingat terdapat kecenderungan dari wajib pajak untuk meminimalkan jumlah pajaknya.

Menurut Frank, Lynch, \& Rego (2009) agresivitas pajak adalah suatu tindakan penghematan pajak yang dirancang melalui perencanaan pajak baik menggunakan cara yang tergolong legal (tax avoidance) atau ilegal (tax evasion). Walau tidak semua tindakan yang melanggar peraturan, namun semakin besar penghematan pajak yang dilakukan oleh perusahaan maka perusahaan tersebut dianggap semakin agresif terhadap pajak.

Riset terdahulu telah mengkaji hubungan kondisi keuangan perusahaan dengan agresivitas pajak. Beberapa diantaranya memfokuskan pada tingkat likuiditas. Likuiditas merupakan rasio yang menunjukkan kemampuan perusahaan dalam memenuhi kewajiban jangka pendek (Kasmir, 2016). Suyanto \& Supramono (2012) menyatakan bahwa perusahaan dengan tingkat likuiditas tinggi menunjukkan keuangan perusahaan dalam kondisi yang sehat dan arus kas perusahaan tersebut berjalan dengan baik sehingga perusahaan tidak enggan untuk membayar seluruh kewajiban jangka pendeknya. Sebaliknya, perusahaan yang memiliki likuiditas rendah mencerminkan perusahaan tersebut kesulitan dalam memenuhi kewajiban jangka pendeknya sehingga hal tersebut dapat mengarah pada tindakan agresivitas pajak perusahaan. Sukmawati \& Rebecca (2016), Putra \& Suryani (2018), dan Fadli (2016) 
menemukan adanya pengaruh likuiditas terhadap agresivitas pajak. Namun, berbeda dengan Suyanto \& Supramono (2012), Tiaras \& Wijaya (2015), dan Putri (2014) yang menemukan tidak adanya pengaruh likuiditas terhadap agresivitas pajak.

Kondisi keuangan lainnya yang diprediksi akan mempengaruhi agresivitas pajak perusahaan adalah leverage. Leverage adalah kemampuan perusahaan menggunakan utang untuk memenuhi kebutuhan operasional dan investasi perusahaan. Leverage menunjukkan seberapa besar aset yang dimiliki perusahaan dibiayai oleh utang. Suyanto \& Supramono (2012) menyatakan bahwa "perusahaan yang memiliki beban pajak tinggi dapat memanfaatkan utang untuk melakukan penghematan pajak". Hal ini disebabkan penggunaan utang bagi perusahaan menimbulkan beban tetap berupa bunga yang boleh dikurangkan sebagai biaya dalam perhitungan pajak penghasilan. Penggunaan utang yang semakin besar akan menimbulkan beban bunga semakin besar pula sehingga menyebabkan berkurangnya laba dan beban pajak akan menjadi lebih kecil. Hasil penelitian Sukmawati \& Rebecca (2016), Suyanto \& Supramono (2012), dan Fadli (2016) menunjukkan terdapat pengaruh leverage terhadap agresivitas pajak. Namun, berbeda dengan hasil penelitian Adisamartha \& Noviari (2015), Tiaras \& Wijaya (2015), Putra \& Suryani (2018) yang menemukan tidak terdapat pengaruh leverage terhadap agresivitas pajak.

Faktor lain yang diprediksi akan mempengaruhi agresivitas pajak adalah komite audit. Komite audit memiliki peran yang signifikan terhadap kebijakan yang diambil perusahaan, khususnya yang terkait dengan kebijakan pajak. Komite audit merupakan suatu komite tambahan yang dibentuk dengan anggota sekurang-kurangnya tiga orang yang bertugas untuk membantu dewan komisaris dalam melakukan fungsi pengawasan atas kinerja perusahaan secara keseluruhan.

Hasil penelitian Nugroho \& Firmansyah (2017) menunjukkan bahwa jumlah anggota komite audit yang banyak dapat melakukan fungsi pengawasan yang lebih baik dan fungsi akuntabilitas sebagaimana dipersyaratkan pada Good Corporate Governance. Sehingga, akan mengurangi tindakan-tindakan manajemen yang bertentangan dengan keinginan shareholder, seperti melakukan penghindaran pajak atau penggelapan pajak. Dengan demikian, perusahaan yang memiliki lebih banyak jumlah anggota komite audit akan mengurangi kemungkinan terjadinya tindakan agresivitas pajak perusahaan.

Ayem \& Afik (2019), Nugroho \& Firmansyah (2017), Diantari \& Ulupui (2016) menemukan adanya pengaruh komite audit terhadap agresivitas pajak. Namun, berbeda dengan Susanto, dkk (2018), Kandaka \& Pratiwi (2019), dan Ratnawati, dkk (2019) yang menemukan tidak adanya pengaruh komite audit terhadap agresivitas pajak. 
Penelitian ini merupakan pengembangan dari penelitian yang dilakukan oleh Sukmawati \& Rebecca (2016) dengan menambahkan variabel komite audit dari penelitian yang dilakukan oleh Ratnawati, dkk (2019) sebagai variabel independen dengan alasan karena dari hasil penelitian terdahulu masih terdapat ketidakkonsistenan pengaruh komite audit terhadap agresivitas pajak, dan tidak hanya faktor kondisi keuangan saja yang diprediksi akan mempengaruhi agresivitas pajak, tetapi faktor non keuangan dari sisi pengawasan juga diprediksi akan mempengaruhi agresivitas pajak seperti komite audit. Penelitian ini menggunakan perusahaan manufaktur yang terdaftar di Bursa Efek Indonesia periode 20162018 sebagai objek penelitian. Dalam penelitian ini, proksi Effective Tax Rate (ETR) digunakan untuk mengukur agresivitas pajak karena merupakan proksi yang paling banyak digunakan di beberapa penelitian sebelumnya, dan nilai ETR yang rendah dapat menjadi indikator adanya agresivitas pajak.

Penelitian ini memliki tujuan untuk menguji dan menganalisis pengaruh likuiditas, leverage, dan komite audit terhadap agresivitas pajak.

\section{PENGEMBANGAN HIPOTESIS}

\section{Pengaruh Likuiditas terhadap Agresivitas Pajak}

Likuiditas merupakan rasio yang mengukur kemampuan perusahaan dalam memenuhi kewajiban jangka pendek (Kasmir, 2016). Likuiditas dapat diukur dengan membandingkan total aset lancar dengan total kewajiban lancar perusahaan. Artinya, seberapa banyak aset lancar perusahaan yang tersedia mampu untuk menutupi kewajiban jangka pendek yang segera jatuh tempo. Perusahaan yang memiliki tingkat likuiditas tinggi disebut perusahaan likuid. Hal ini bisa digambarkan bahwa keuangan perusahaan dalam kondisi yang sehat dan perputaran arus kasnya lancar karena jumlah aset lancar perusahaan yang tersedia lebih besar dibandingkan jumlah kewajiban jangka pendeknya sehingga perusahaan mampu memenuhi seluruh kewajiban jangka pendeknya termasuk membayar pajak sesuai dengan ketentuan yang berlaku (Suyanto \& Supramono, 2012). Oleh karena itu, semakin tinggi tingkat likuiditas perusahaan maka agresivitas pajak semakin rendah, sebaliknya semakin rendah tingkat likuiditas perusahaan maka agresivitas pajak semakin tinggi.

Penelitian Siahaan (2005) memberikan bukti bahwa perusahaan yang memiliki tingkat likuiditas rendah menunjukkan bahwa perusahaan tersebut mengalami kesulitan untuk memenuhi kewajiban jangka pendeknya sehingga perusahaan cenderung melakukan tindakan agresivitas pajak. Tindakan ini dilakukan perusahaan untuk mengurangi pengeluaran beban pajaknya. Temuan Sukmawati \& Rebecca (2016), Putra \& Suryani (2018), dan Fadli (2016) 
menunjukkan adanya pengaruh likuiditas terhadap agresivitas pajak. Namun, berbeda dengan penelitian Suyanto \& Supramono (2012), Tiaras \& Wijaya (2015), dan Putri (2014) yang menemukan bahwa tidak adanya pengaruh likuiditas terhadap agresivitas pajak. Berdasarkan uraian di atas, penelitian ini mengajukan hipotesis sebagai berikut:

\section{$\mathrm{H}_{1}$ : Likuiditas berpengaruh terhadap Agresivitas Pajak.}

\section{Pengaruh Leverage terhadap Agresivitas Pajak}

Leverage adalah penggunaan sumber dana (source of funds) oleh perusahaan yang memiliki beban tetap untuk membiayai kebutuhan operasional dan investasi perusahaan. Menurut Kasmir (2016:151), leverage merupakan rasio yang mengukur seberapa besar aset perusahaan dibiayai dengan utang. Penggunaan utang bagi perusahaan akan menimbulkan beban tetap berupa bunga yang boleh dikurangkan dalam perhitungan pajak penghasilan. Semakin banyak jumlah utang yang digunakan perusahaan maka beban bunga yang harus dibayarkan semakin tinggi. Semakin tinggi tarif bunga akan semakin besar keuntungan yang diperoleh perusahaan dari penggunaan utang tersebut. Hal ini dikarenakan bunga yang timbul dari penggunaan utang dapat mengurangi laba dan menyebabkan beban pajak menjadi lebih kecil. Dengan demikian, semakin tinggi leverage perusahaan maka akan meningkatkan terjadinya agresivitas pajak perusahaan.

Penelitian Ozkan (2001) memberikan bukti bahwa perusahaan yang memiliki beban pajak tinggi lebih banyak memanfaatkan utang guna mendapatkan keuntungan dari pengurangan bunga atas utang tersebut sehingga beban pajak yang dibayar akan menjadi lebih kecil. Perusahaan yang dengan sengaja meminimalkan beban pajak dengan cara menambah hutang dalam jumlah yang besar maka perusahaan tersebut dianggap semakin agresif terhadap pajak. Temuan Sukmawati \& Rebecca (2016), Suyanto \& Supramono (2012), dan Fadli (2016) menunjukkan adanya pengaruh leverage terhadap agresivitas pajak. Namun, berbeda dengan penelitian Adisamartha \& Noviari (2015), Tiaras \& Wijaya (2015), Putra \& Suryani (2018) yang menemukan tidak adanya pengaruh leverage terhadap agresivitas pajak. Berdasarkan uraian di atas, penelitian ini mengajukan hipotesis sebagai berikut:

\section{$\mathrm{H}_{2}$ : Leverage berpengaruh terhadap Agresivitas Pajak.}

\section{Pengaruh Komite Audit terhadap Agresivitas Pajak}

Komite audit merupakan komite yang dibentuk oleh dewan komisaris untuk membantu melakukan pengawasan atas kinerja perusahaan dengan beranggotakan sekurangkurangnya tiga orang anggota (Peraturan Otoritas Jasa Keuangan Nomor 55/POJK.04/2015). Salah seorang dari anggota komite audit wajib berlatar belakang pendidikan dan keahlian di 
bidang akuntansi dan keuangan agar dapat memudahkan anggota komite audit dalam memahami dan memberikan pandangan mengenai hal-hal yang berhubungan dengan masalah keuangan sehingga akan meningkatkan efektivitas kinerjanya dalam mengawasi proses pelaporan keuangan perusahaan. Dengan adanya pengawasan dari komite audit maka kemungkinan perusahaan untuk melakukan tindakan agresivitas pajak cenderung berkurang.

Penelitian Lin (2006) membuktikan bahwa kualitas pelaporan keuangan akan semakin terjamin dengan banyaknya jumlah komite audit yang dimiliki suatu perusahaan. Hal ini menunjukkan bahwa berjalannya fungsi komite audit secara efektif dan sesuai dengan prinsip tata kelola perusahaan memungkinkan pengendalian pada perusahaan dan laporan keuangan yang lebih baik sehingga dapat mencegah kemungkinan terjadinya kecurangan yang akan dilakukan oleh pihak manajemen. Dengan demikian, perusahaan dengan jumlah anggota komite audit yang lebih banyak akan cenderung tidak terlibat agresivitas pajak perusahaan. Ayem \& Afik (2019), Nugroho \& Firmansyah (2017), Diantari \& Ulupui (2016) menemukan adanya pengaruh komite audit terhadap agresivitas pajak. Namun, hasil yang berbeda ditemukan oleh Susanto, dkk (2018), Kandaka \& Pratiwi (2019), dan Ratnawati, dkk (2019) yang menyatakan bahwa tidak adanya pengaruh komite audit terhadap agresivitas pajak. Berdasarkan uraian di atas, penelitian ini mengajukan hipotesis sebagai berikut:

\section{$\mathrm{H}_{3}$ : Komite audit berpengaruh terhadap Agresivitas Pajak.}

\section{Kerangka Berfikir}

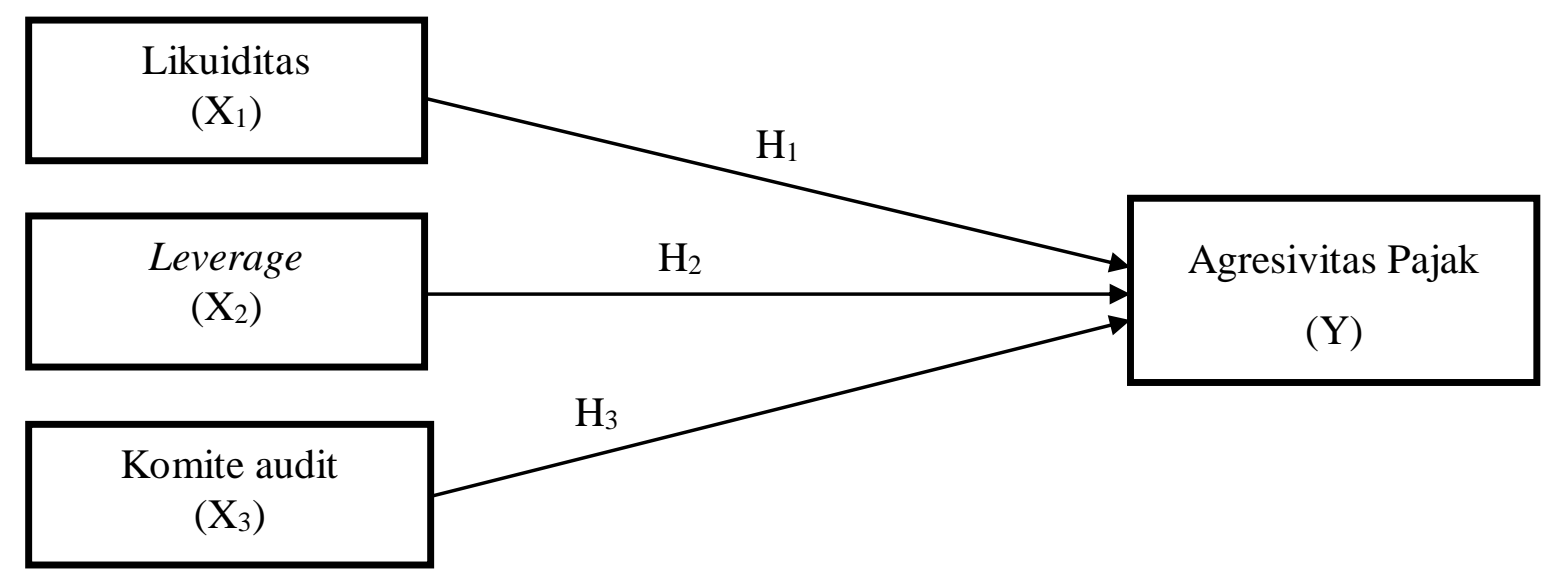

\section{Gambar 1}

Kerangka Konseptual Variabel Independen terhadap Variabel Dependen.

Sumber: Data Olahan (2020) 


\section{METODE PENELITIAN}

\section{Lokasi Penelitian}

Penelitian ini dilakukan pada Bursa Efek Indonesia (BEI). Hal ini dikarenakan Bursa Efek Indonesia merupakan salah satu pusat penjualan saham perusahaan yang go public di Indonesia.

\section{Populasi dan Sampel}

Populasi dalam penelitian ini adalah perusahaan manufaktur yang terdaftar di Bursa Efek Indonesia periode 2016-2018 dengan jumlah populasi sebanyak 147 perusahaan.

Sedangkan, sampel yang digunakan dalam penelitian ini adalah 74 perusahaan. Total data yang akan diolah selama 3 tahun (periode penelitian 2016-2018) sebanyak 222 laporan keuangan perusahaan. Pengambilan sampel ini dilakukan dengan menggunakan metode purposive sampling, yaitu teknik penentuan sampel dengan pertimbangan atau kriteria tertentu. Proses pemilihan sampel dalam penelitian ini dapat dilihat pada tabel 1 berikut:

\section{Tabel 1}

\section{Proses Seleksi Sampel Berdasarkan Kriteria}

\begin{tabular}{llc}
\hline No & \multicolumn{1}{c}{ Kriteria } & Jumlah \\
\hline & Perusahaan manufaktur yang terdaftar di Bursa Efek Indonesia periode 2016-2018 & 147 \\
\hline & Dikurangi: & \\
\hline 1. & Perusahaan manufaktur yang delisting selama periode penelitian & 5 \\
2. & Perusahaan manufaktur yang tidak menyajikan laporan keuangan dalam mata & 28 \\
& uang rupiah & 4 \\
3. & Perusahaan manufaktur yang memiliki manfaat pajak penghasilan & 36 \\
4. Perusahaan manufaktur yang mengalami kerugian sebelum pajak selama tahun & 36 \\
\hline Jumlah Sampel Perusahaan & $\mathbf{7 4}$ \\
Tahun Pengamatan & 3 \\
Total data yang akan diolah & $\mathbf{2 2 2}$ \\
\hline
\end{tabular}

Sumber: Bursa Efek Indonesia

\section{Jenis dan Sumber Data}

Jenis penelitian ini adalah penelitian kuantitatif dengan sumber data yang digunakan yaitu data sekunder. Data sekunder yang digunakan dalam penelitian ini yaitu berupa laporan keuangan dan annual report perusahaan manufaktur yang telah dipublikasikan di Bursa Efek Indonesia pada periode 2016-2018.

\section{Teknik Pengumpulan Data}

Teknik pengumpulan data dalam penelitian ini adalah menggunakan teknik dokumentasi yaitu dengan mencari dan mengumpulkan data dari perusahaan yang menerbitkan laporan keuangan dan annual report di BEI atau di situs resmi milik perusahaan 
yang menjadi sampel penelitian ini.

\section{Definisi Operasional dan Pengukuran Variabel}

\section{Variabel Dependen}

Agresivitas pajak adalah suatu tindakan penghematan pajak yang dirancang melalui perencanaan pajak baik menggunakan cara yang tergolong legal (tax avoidance) atau ilegal (tax evasion) (Frank, dkk, 2009). Proksi yang digunakan untuk mengukur agresivitas pajak adalah Effective Tax Rate (ETR) yaitu membandingkan antara total beban pajak penghasilan yang dibayarkan perusahaan dengan pendapatan sebelum pajak. Semakin tinggi nilai ETR yaitu mendekati tarif pajak penghasilan badan sebesar $25 \%(0,25)$ menunjukkan bahwa semakin rendah tingkat agresivitas pajak yang dilakukan perusahaan. Adapun persamaan untuk menghitung Effective Tax Rate (ETR) adalah sebagai berikut:

$$
\text { Effective Tax Rate }(\text { ETR })=\frac{\text { TotalBeban Pajak Penghasilan }}{\text { Pendapatan Sebehun Pajak }}
$$

\section{Variabel Independen}

\section{Likuiditas}

Likuiditas adalah kemampuan perusahaan untuk memenuhi kewajiban jangka pendek (Suyanto \& Supramono, 2012). Indikator yang paling sering digunakan dalam mengukur likuiditas perusahaan adalah rasio lancar (current ratio). Rasio lancar merupakan perbandingan antara aset lancar perusahaan dengan kewajiban lancarnya. Semakin tinggi tingkat likuditas perusahaan menunjukkan aset lancar perusahaan yang tersedia mampu untuk memenuhi kewajiban jangka pendeknya sehingga tingkat agresivitas pajak perusahaan semakin rendah. Rasio lancar menurut Kasmir (2016:135), dirumuskan sebagai berikut:

$$
\text { Rasio Lancar }=\frac{\text { Aset Lancar }}{\text { Kewajiban Lancar }}
$$

\section{Leverage}

Leverage merupakan kemampuan utang baik jangka panjang maupun jangka pendek untuk membiayai aset perusahaan (Kurniasih \& Sari, 2013). Leverage diproksikan dengan Debt to Asset Ratio (DAR). Rasio ini menggambarkan proksi total kewajiban perusahaan terhadap total aset yang dimiliki perusahaan dengan tujuan untuk mengetahui seberapa besar aset yang dimiliki perusahaan dibiayai oleh utang. Debt to Asset Ratio (DAR) menurut Kasmir (2016:156), dirumuskan sebagai berikut: 


$$
\text { Debt to Asset Ratio }(D A R)=\frac{\text { Total Kewajiban }}{\text { Total Aset }}
$$

\section{Komite Audit}

Komite audit adalah komite tambahan yang dibentuk oleh dewan komisaris yang bertujuan untuk melakukan kontrol terhadap proses penyusunan laporan keuangan perusahaan untuk menghindari kecurangan pihak manajemen (Diantari \& Ulupui, 2016). Komite audit paling sedikit terdiri dari tiga orang anggota. Komite audit dalam penelitian ini diukur dengan menghitung jumlah anggota komite audit dalam suatu perusahaan. Proksi ini digunakan agar dapat diketahui seberapa banyak komite audit yang dimiliki perusahaan dan seberapa besar pengaruh komite audit dalam pengawasan pengelolaan perusahaan.

$$
\text { Komite Audit }=\sum \text { Anggota Komite Audit }
$$

\section{Metode Analisis Data}

Metode analisis data yang digunakan adalah metode analisis data kuantitatif yang diolah dengan program SPSS versi 25. Pengujian hipotesis dalam penelitian ini menggunakan analisis regresi linier berganda (multiple linear regression). Adapun model persamaan regresi linier berganda yang digunakan dalam penelitian ini adalah sebagai berikut:

$$
\mathrm{Y}=\alpha+\beta_{1} \mathrm{X}_{1}+\beta_{2} \mathrm{X}_{2}+\beta_{3} \mathrm{X}_{3}+\varepsilon
$$

Keterangan:

$$
\begin{array}{ll}
\mathrm{Y} & =\text { Agresivitas Pajak } \\
\alpha & =\text { Konstanta } \\
\beta_{1}, \beta_{2}, \beta_{3} & =\text { Koefisien regresi } \\
\mathrm{X}_{1} & =\text { Likuiditas } \\
\mathrm{X}_{2} & =\text { Leverage } \\
\mathrm{X}_{3} & =\text { Komite Audit } \\
\varepsilon & =\text { Error }
\end{array}
$$

\section{HASIL PENELITIAN DAN PEMBAHASAN}

\section{Hasil Uji Statistik Deskriptif}

Statistik deskriptif pada penelitian ini terdiri dari nilai minimum (min), maximum (max), mean, dan standard deviation. Hasil uji statistik deskriptif dalam penelitian ini disajikan pada tabel 2 berikut: 
Tabel 2

\section{Hasil Uji Statistik Deskriptif}

\begin{tabular}{lcccrc}
\hline & N & Minimum & Maximum & Mean & Std. Deviation \\
\hline Agresivitas Pajak & 222 &, 012 & 1,805 &, 285 &, 177 \\
Likuiditas & 222 &, 001 & 15,165 & 2,570 & 1,905 \\
Leverage & 222 &, 077 &, 832 &, 402 &, 179 \\
Komite Audit & 222 & 3,00 & 5,00 & 3,090 &, 302 \\
Valid N (listwise) & 222 & & & & \\
\hline
\end{tabular}

Sumber: Data Olahan dengan SPSS (2020)

Dari tabel 2 diketahui bahwa variabel agresivitas pajak (Y) memiliki nilai rata-rata 0,285 serta standar deviasi sebesar 0,177 dengan nilai minimum berada pada nilai 0,012 dan nilai maksimum berada di nilai 1,805. Variabel likuiditas $\left(\mathrm{X}_{1}\right)$ memiliki nilai rata-rata 2,570 serta standar deviasi sebesar 1,905 dengan nilai minimum berada pada nilai 0,001 dan nilai maksimum berada di nilai 15,165 . Variabel leverage $\left(\mathrm{X}_{2}\right)$ memiliki nilai rata-rata 0,402 serta standar deviasi sebesar 0,179 dengan nilai minimum berada pada nilai 0,077 dan nilai maksimum berada di nilai 0,832. Variabel komite audit $\left(\mathrm{X}_{3}\right)$ memiliki nilai rata-rata 3,090 serta standar deviasi sebesar 0,302 dengan minimum berada pada nilai 3,00 dan nilai maksimum berada di nilai 5,00.

\section{Hasil Uji Asumsi Klasik}

\section{Hasil Uji Normalitas}

Uji normalitas bertujuan untuk menguji variabel pengganggu atau residual dalam model regresi memiliki distribusi normal atau tidak (Ghozali, 2018). Salah satu cara uji normalitas yaitu menggunakan uji One-Sample Kolmogorov-Smirnov. Apabila nilai Asymp. Sig. (2-tailed) $>0,05$ maka data telah memenuhi asumsi normalitas dan terdistribusi normal. Hasil uji normalitas menggunakan Kolmogorov-Smirnov disajikan pada tabel 3.

\section{Tabel 3}

\section{Hasil Uji Normalitas}

\begin{tabular}{|c|c|c|}
\hline \multicolumn{3}{|c|}{ One-Sample Kolmogorov-Smirnov Test } \\
\hline & & Unstandardized Residual \\
\hline $\mathrm{N}$ & & 222 \\
\hline \multirow{2}{*}{ Normal Parameters ${ }^{\mathrm{a}, \mathrm{b}}$} & Mean & ,0000000 \\
\hline & Std. Deviation & 09102953 \\
\hline \multirow[t]{3}{*}{ Most Extreme Differences } & Absolute &, 026 \\
\hline & Positive & ,026 \\
\hline & Negative &,- 023 \\
\hline Test Statistic & & 026 \\
\hline Asymp. Sig. (2-tailed) & & $200^{\mathrm{c}, \mathrm{d}}$ \\
\hline
\end{tabular}

Sumber: Data Olahan dengan SPSS (2020) 


\section{Hasil Uji Multikolonieritas}

Uji Multikolinearitas dilakukan dengan matriks korelasi dengan melihat besarnya nilai Variance Inflation Factor (VIF) dan nilai tolerance. Suatu model regresi yang bebas dari multikolinearitas memiliki nilai VIF $\leq 10$ dan nilai tolerance $\geq 0,10$. Hasil uji multikolonieritas disajikan pada tabel 4 berikut:

\section{Tabel 4}

\section{Hasil Uji Multikolonieritas}

\begin{tabular}{llcccc}
\hline & & \multicolumn{2}{c}{ Coefficients $^{\mathbf{a}}$} & \\
\hline & & \multicolumn{2}{c}{ Collinearity Statistics } & \\
\cline { 3 - 4 } & Model & Tolerance & VIF & Keterangan \\
\hline \multirow{2}{*}{1} & Likuiditas &, 843 & 1,186 & & Bebas Multikolonieritas \\
& Leverage &, 908 & 1,101 & & Bebas Multikolonieritas \\
& Komite Audit &, 818 & 1,222 & & Bebas Multikolonieritas \\
\hline
\end{tabular}

Sumber: Data Olahan dengan SPSS (2020).

\section{Hasil Uji Autokorelasi}

Uji autokorelasi digunakan untuk menguji apakah model regresi linier ada korelasi antara kesalahan pengganggu pada periode $\mathrm{t}$ dengan kesalahan pada periode $\mathrm{t}-1$ (periode sebelumnya) (Ghozali, 2018). Dalam penelitian ini, pengujian autokorelasi akan dilakukan dengan menggunakan uji Durbin-Watson. Hasil uji autokorelasi disajikan pada tabel 5.

\section{Tabel 5}

\section{Hasil Uji Autokorelasi}

\begin{tabular}{|c|c|c|}
\hline \multicolumn{3}{|c|}{ Model Summary $^{\mathrm{b}}$} \\
\hline Model & Durbin-Watson & Keterangan \\
\hline 1 & 2,037 & Tidak terjadi autokorelasi \\
\hline
\end{tabular}

Sumber: Data Olahan dengan SPSS (2020).

Tabel 5 menunjukkan nilai Durbin-Watson sebesar 2,037. Dengan jumlah data $(\mathrm{n})=$ 222 dan jumlah variabel bebas $(\mathrm{k})=3$, diperoleh nilai du sebesar 1,79753. Dari perhitungan $(\mathrm{du}<\mathrm{d}<4-\mathrm{du})$ atau $(1,79753<2,037<2,20247)$ dapat disimpulkan bahwa nilai DurbinWatson terletak pada daerah yang tidak terjadi autokorelasi.

\section{Hasil Uji Heteroskedastisitas}

Uji heteroskedastisitas dilakukan dengan menggunakan uji Glejser. Model regresi tidak mengalami atau bebas dari heteroskedastisitas apabila nilai signifikansi $>0,05$. Hasil dari uji heteroskedastisitas disajikan pada tabel 6 berikut: 
Tabel 6

Hasil Uji Heteroskedastisitas

\begin{tabular}{llccccc}
\hline \multicolumn{7}{c}{ Coefficients $^{\mathbf{a}}$} \\
\hline & & \multicolumn{7}{c}{$\begin{array}{c}\text { Unstandardized } \\
\text { Coefficients }\end{array}$} & $\begin{array}{c}\text { Standardized } \\
\text { Coefficients }\end{array}$ & & \\
\cline { 3 - 5 } & Model & B & Std. Error & Beta & t & Sig. \\
\hline 1 & (Constant) &, 032 &, 203 & &, 160 &, 873 \\
& Likuiditas &,- 019 &, 019 &,- 070 & $-1,005$ &, 316 \\
& Leverage &,- 022 &, 040 &,- 039 &,- 550 &, 583 \\
& Komite Audit &, 176 &, 185 &, 068 &, 952 &, 342 \\
\hline
\end{tabular}

Sumber: Data Olahan dengan SPSS (2020).

\section{Hasil Uji Koefisien Determinasi}

Hasil uji koefisien determinasi disajikan pada tabel 7 berikut:

Tabel 7

Hasil Uji Koefisien Determinasi

\begin{tabular}{ccccc}
\hline \multicolumn{5}{c}{ Model Summary $^{\mathbf{b}}$} \\
\hline Model & R & R Square & Adjusted R Square & Std. Error of the Estimate \\
\hline 1 &, $643^{\text {a }}$ &, 414 &, 406 &, 36760 \\
\hline
\end{tabular}

Sumber: Data Olahan dengan SPSS (2020).

Tabel 7 menunjukkan bahwa nilai Adjusted R Square $\left(\mathrm{R}^{2}\right)$ sebesar 0,406. Hal ini berarti bahwa variabel bebas yang meliputi likuiditas, leverage, dan komite audit dapat menjelaskan variasi variabel terikat yaitu agresivitas pajak sebesar 40,6\%. Sedangkan, sisanya sebesar 59,4\% dipengaruhi oleh variabel-variabel lain diluar penelitian.

\section{Hasil Analisis Regresi Linier Berganda}

Hasil analisis regresi linier berganda disajikan pada tabel 8 berikut:

\section{Tabel 8}

Hasil Uji Analisis Regresi Linear Berganda

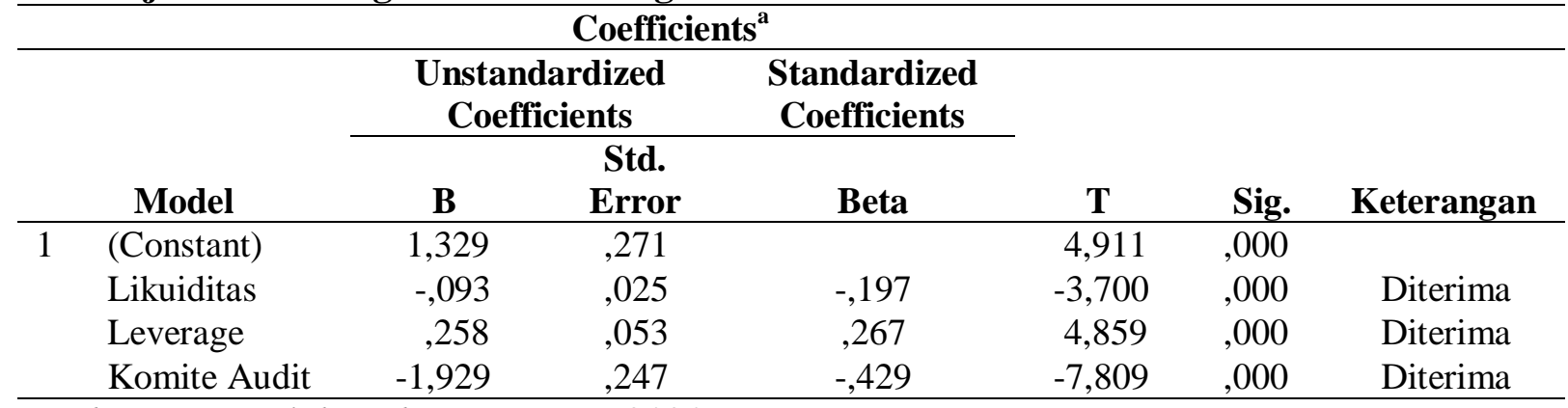

Sumber: Data Olahan dengan SPSS (2020).

Dari tabel 8 dapat diketahui bahwa persamaan regresi linier berganda dapat dirumuskan sebagai berikut:

$$
\begin{aligned}
& Y=\alpha+\beta_{1} X_{1}+\beta_{2} X_{2}+\beta_{3} X_{3}+\varepsilon \\
& Y=1,329-0,093 X_{1}+0,258 X_{2}-1,929 X_{3}+\varepsilon
\end{aligned}
$$




\section{Hasil Pengujian Hipotesis}

Penelitian ini menggunakan uji t untuk mengetahui apakah likuiditas $\left(\mathrm{X}_{1}\right)$, leverage $\left(\mathrm{X}_{2}\right)$, dan komite audit $\left(\mathrm{X}_{3}\right)$ secara parsial berpengaruh terhadap agresivitas pajak $(\mathrm{Y})$. Pengambilan keputusan dalam uji ini adalah jika probabilitas < tingkat signifikansi ( $p$-value < 0,05) atau $\mathrm{t}$ hitung $>\mathrm{t}$ tabel, maka $\mathrm{H}_{\mathrm{a}}$ diterima dan $\mathrm{H}_{0}$ ditolak, sehingga variabel independen berpengaruh terhadap variabel dependen. Sebaliknya, jika probabilitas > tingkat signifikansi ( $p$-value $>0,05)$ atau $\mathrm{t}$ hitung $<\mathrm{t}$ tabel, maka $\mathrm{H}_{\mathrm{a}}$ ditolak dan $\mathrm{H}_{0}$ diterima, sehingga variabel independen tidak berpengaruh terhadap variabel dependen.

\section{Pengaruh Likuiditas terhadap Agresivitas Pajak}

Hasil pengujian menunjukkan bahwa nilai $p$-value likuiditas $(0,000<0,05)$ dan diperkuat dengan nilai $-t_{\text {hitung }}<-t_{\text {tabel }}$ yaitu $(-3,700<-1,971)$ sehingga dapat disimpulkan bahwa $\mathrm{H}_{0}$ ditolak dan $\mathrm{H}_{\mathrm{a}}$ diterima. Hal ini mengindikasikan, likuiditas secara signifikan mempengaruhi agresivitas pajak.

Hasil penelitian ini mengindikasikan bahwa semakin tinggi tingkat likuiditas suatu perusahaan berarti semakin tinggi jumlah aset lancar perusahaan yang tersedia untuk memenuhi kewajiban jangka pendek perusahaan, yang mengakibatkan tingkat agresivitas pajak perusahaan akan semakin rendah. Perusahaan yang memiliki tingkat likuiditas tinggi menunjukkan bahwa perusahaan tidak mengalami kesulitan dalam memenuhi kewajiban jangka pendeknya, hal ini disebabkan karena kondisi keuangan perusahaan tersebut sehat dan perputaran arus kasnya lancar sehingga perusahaan mampu memenuhi seluruh kewajiban jangka pendeknya (Sukmawati \& Rebecca, 2016). Sebaliknya, perusahaan dengan tingkat likuiditas yang rendah menunjukkan bahwa perusahaan tersebut mengalami kesulitan untuk memenuhi kewajiban jangka pendeknya, hal ini disebabkan jumlah aset lancar perusahaan yang tersedia tidak mampu untuk memenuhi kewajiban jangka pendek perusahaan, sehingga perusahaan akan cenderung melakukan tindakan agresivitas pajak. Dengan demikian dapat diketahui bahwa selama periode pengamatan, perusahaan manufaktur di Indonesia dengan rasio likuiditas tinggi akan memiliki tingkat agresivitas pajak yang rendah, dan perusahaan dengan rasio likuiditas rendah akan cenderung memiliki tingkat agresivitas pajak yang tinggi.

Hasil penelitian ini mendukung penelitian Anita (2015), Sukmawati \& Rebecca (2016), dan Fadli (2016) yang menemukan adanya pengaruh likuiditas terhadap agresivitas pajak. Tetapi hasil penelitian ini tidak sejalan dengan penelitian Suyanto \& Supramono (2012), Tiaras \& Wijaya (2015), dan Putri (2014) yang menemukan hasil bahwa tidak ada pengaruh likuiditas terhadap agresivitas pajak. 
Pengaruh Leverage terhadap Agresivitas Pajak

Hasil pengujian menunjukkan bahwa nilai p-value leverage $(0,000<0,05)$ dan diperkuat dengan nilai $t_{\text {hitung }}>\mathrm{t}_{\text {tabel }}$ yaitu $(4,859>1,971)$ sehingga dapat disimpulkan bahwa $\mathrm{H}_{0}$ ditolak dan $\mathrm{H}_{\mathrm{a}}$ diterima. Hal ini mengindikasikan, leverage secara signifikan mempengaruhi agresivitas pajak.

Hasil penelitian ini mengindikasikan bahwa semakin tinggi tingkat leverage suatu perusahaan berarti semakin besar proporsi aset perusahaan yang dibiayai oleh utang dan semakin tinggi pula kewajiban yang harus dipenuhi, yang mengakibatkan tingkat agresivitas pajak perusahaan akan semakin meningkat. Hal ini dikarenakan penggunaan utang bagi perusahaan menimbulkan beban tetap berupa beban bunga yang dapat dikurangkan sebagai biaya (deductible expense) dalam penghitungan pajak penghasilan. Semakin tinggi jumlah utang yang digunakan untuk membiayai aset perusahaan maka semakin tinggi beban bunga yang harus dibayarkan sehingga akan mengurangi laba dan menyebabkan beban pajak menjadi lebih kecil. Menurut Suyanto \& Supramono (2012), perusahaan yang memiliki kewajiban pajak tinggi dapat memanfaatkan utang untuk melakukan penghematan pajak. Suatu perusahaan dikatakan agresif terhadap pajaknya apabila dengan sengaja perusahaan tersebut menambah jumlah utang agar memperoleh insentif pajak yang besar berupa bunga yang mengakibatkan berkurangnya beban pajak perusahaan. Oleh karena itu, semakin tinggi tingkat leverage suatu perusahaan maka akan semakin tinggi tingkat agresivitas pajak perusahaan. Dengan demikian dapat diketahui bahwa selama periode pengamatan, perusahaan manufaktur di Indonesia memanfaatkan penggunaan utang untuk meminimalkan beban pajak perusahaan.

Hasil penelitian ini mendukung penelitian Sukmawati \& Rebecca (2016), Suyanto \& Supramono (2012), dan Fadli (2016) yang menemukan terdapat pengaruh leverage terhadap agresivitas pajak. Tetapi hasil penelitian ini tidak sejalan dengan penelitian Adisamartha \& Noviari (2015), Tiaras \& Wijaya (2015), Putra \& Suryani (2018) yang menemukan hasil bahwa tidak ada pengaruh leverage terhadap agresivitas pajak.

\section{Pengaruh Komite Audit terhadap Agresivitas Pajak}

Hasil pengujian menunjukkan bahwa nilai p-value komite audit $(0,000<0,05)$ dan diperkuat dengan nilai $-\mathrm{t}_{\text {hitung }}<-\mathrm{t}_{\text {tabel }}$ yaitu $(-7,809<-1,971)$ sehingga dapat disimpulkan bahwa $\mathrm{H}_{0}$ ditolak dan $\mathrm{H}_{\mathrm{a}}$ diterima. Hal ini mengindikasikan, komite audit secara signifikan mempengaruhi agresivitas pajak. Hasil penelitian ini mengindikasikan bahwa keberadaan komite audit dalam suatu perusahaan memberikan pengaruh terhadap kebijakan yang diambil 
perusahaan, khususnya yang terkait dengan kebijakan pajak. Bursa Efek Indonesia mewajibkan komite audit paling sedikit terdiri dari tiga orang anggota. Perusahaan yang tidak memiliki jumlah komite audit sesuai dengan peraturan tersebut menyebabkan tindakan untuk meminimalisasi laba dalam rangka kepentingan pajak yang dilakukan oleh manajemen akan semakin meningkat (Pohan, 2008). Berdasarkan hasil penelitian ini, rata-rata perusahaan memiliki tiga atau empat orang anggota komite audit, yang berarti sampel dalam penelitian ini sudah memenuhi persyaratan yang telah ditetapkan mengenai jumlah komite audit.

Di dalam perusahaan, komite audit berfungsi membantu dewan komisaris untuk melakukan kontrol terhadap proses penyusunan laporan keuangan dan pengendalian internal perusahaan guna mencegah kecurangan yang akan dilakukan oleh pihak manajemen. Perusahaan dengan jumlah komite audit yang semakin banyak akan meningkatkan sistem pengawasan atas kinerja perusahaan menjadi lebih baik sehingga dapat mengurangi kemungkinan terjadinya agresivitas pajak. Dengan demikian dapat diketahui bahwa selama periode pengamatan, komite audit pada perusahaan manufaktur di Indonesia telah menjalankan tugas dan fungsinya sesuai dengan prinsip yang berlaku dalam melakukan pengawasan terhadap kinerja perusahaan.

Hasil penelitian ini sejalan dengan penelitian yang dilakukan Nugroho \& Firmansyah (2017), Diantari \& Ulupui (2016), dan Yanti (2019) yang menemukan adanya pengaruh komite audit terhadap agresivitas pajak. Tetapi hasil penelitian ini tidak sejalan dengan penelitian Susanto, dkk (2018), Kandaka \& Pratiwi (2019), dan Ratnawati, dkk (2019) yang menemukan hasil bahwa tidak ada pengaruh komite audit terhadap agresivitas pajak.

\section{SIMPULAN}

Hasil penelitian ini menyimpulkan bahwa dari ketiga variabel yakni likuiditas, leverage, dan komite audit berpengaruh terhadap agresivitas pajak. Keterbatasan pada penelitian ini di antaranya hanya berfokus pada perusahaan manufaktur yang terdaftar di Bursa Efek Indonesia periode 2016-2018, sehingga implikasinya mungkin memiliki perbedaan hasil jika periode penelitian diperpanjang. Selain itu, penelitian ini juga belum mampu menggambarkan secara keseluruhan mengenai faktor-faktor yang dapat mempengaruhi agresivitas pajak karena penelitian ini hanya menggunakan likuiditas, leverage, dan komite audit sebagai variabel independen.

Berdasarkan keterbatasan penelitian seperti yang dijelaskan di atas, berikut beberapa perbaikan yang disarankan untuk peneliti selanjutnya, antara lain (1) Peneliti selanjutnya diharapkan dapat menambah rentang waktu penelitian dan luas cakupan sampel dengan 
menambah lebih banyak sektor perusahaan di bidang lain agar dapat meningkatkan keakuratan dalam hasil yang ditemukan, (2) Peneliti selanjutnya diharapkan dapat menambah variabel-variabel independen, seperti manajemen laba, profitabilitas, kepemilikan institusional, komisaris independen, dan ukuran perusahaan yang diperkirakan dapat mempengaruhi agresivitas pajak.

Implikasi dalam penelitian ini diharapkan agar Direktorat Jenderal Pajak (DJP) untuk dapat lebih meningkatkan pengawasan terhadap perusahaan-perusahaan manufaktur yang memiliki tingkat utang yang tinggi, dikarenakan tingkat utang yang tinggi memiliki beban bunga yang tinggi. Dalam hal ini, mengindikasikan perusahaan memiliki kemungkinan untuk memanfaatkan beban bunga untuk meminimalkan beban pajak yang dibayarkan oleh perusahaan. Hasil penelitian ini juga memberikan implikasi kepada perusahaan manufaktur yang menjadi objek penelitian agar lebih mempertimbangkan faktor-faktor yang mempengaruhi agresivitas pajak. Melalui penelitian ini, perusahaan-perusahaan manufaktur diharapkan mampu menurunkan potensi agresivitas pajak sehingga dapat menarik investor untuk berinvestasi pada perusahaan mereka. Seperti pada hasil penelitian ini, apabila perusahaan ingin menurunkan tingkat agresivitas pajak maka perusahaan dapat meningkatkan rasio likuiditasnya dengan cara mengelola perputaran kas agar perusahaan tidak kesulitan untuk memenuhi seluruh kewajibannya termasuk kewajiban membayar pajak. Perusahaan juga harus mampu membatasi penggunaan utang yang terlalu besar untuk membiayai aset perusahaan, karena penggunaan utang yang terlalu besar dapat menggambarkan risiko yang besar pula. Selain itu, perusahaan juga sebaiknya dapat meningkatkan peran komite audit dalam melakukan pengawasan terhadap kinerja perusahaan agar perusahaan tidak terlibat tindakan agresivitas pajak dan tidak terkena sanksi perpajakan.

Hasil penelitian ini juga memberikan implikasi kepada peneliti selanjutnya sebagai bahan masukan untuk menambah wawasan mengenai faktor-faktor yang mempengaruhi agresivitas pajak pada perusahaan manufaktur sehingga dapat menjadi rujukan dalam mengembangkan penelitian yang sejenis. Penelitian ini menguji faktor-faktor yang mempengaruhi agresivitas pajak, dimana variabel yang diteliti terdiri dari variabel yang masih belum konsisten dari penelitian sebelumnya. Penelitian ini juga membuktikan bahwa variabelvariabel independen penelitian terbukti berpengaruh terhadap agresivitas pajak. Penelitian ini diharapkan dapat memperkaya pengembangan ilmu perpajakan, dimana hasil penelitian ini dapat berkontribusi menambah bukti empiris mengenai faktor yang mempengaruhi agresivitas pajak. 


\section{REFERENSI}

Adisamartha, I.B.P.F., \& Naniek, N. (2015). Pengaruh Likuiditas, Leverage, Intensitas Persediaan dan Intensitas Aset Tetap Pada Tingkat Agresivitas Wajib Pajak Badan. EJurnal Akuntansi Universitas Udayana, 13 (3), pp. 973-1000.

Anita, F. (2015). Pengaruh Corporate Social Responsibility, Leverage, Likuiditas, dan Ukuran Perusahaan Terhadap Agresivitas Pajak (Studi Empiris Pada Perusahaan Real Estate dan Property yang Terdaftar Di Bursa Efek Indonesia Tahun 2010-2013). Jurnal Online Mahasiswa Fakultas Ekonomi, 2 (2), pp. 1-15.

Ayem, S., \& Afik, S. (2019). Pengaruh Profitabilitas, Ukuran Perusahaan, Komite Audit Dan Capital Intensity Terhadap Agresivitas Pajak (Studi Pada Perusahaan Perbankan Yang Terdaftar di BEI Periode Tahun 2013-2017). Jurnal Akuntansi Pajak Dewantara, 1 (2), pp. 228-241.

Diantari, P. R., \& Ulupi, I. G. K. A. (2016). Pengaruh Komite Audit, Proporsi Komisaris Independen, dan Proporsi Kepemilikan Institusional Terhadap Tax Avoidance. EJurnal Akuntansi Universitas Udayana, 16 (1), pp. 702-32.

Fadli, I. (2016). Pengaruh Likuiditas, Leverage, Komisaris Independen, Manajemen Laba, dan Kepemilikan Institusional Terhadap Agresivitas Pajak Perusahaan (Studi Pada Perusahaan Manufaktur yang Terdaftar di Bursa Efek Indonesia Periode 2011-2013). Jurnal Online Mahasiswa Fakultas Ekonomi, 3 (1), pp. 1206-1219.

Frank, M. M., Luann, J. L., \& Sonja, O. R. (2009). Tax Reporting Aggressiveness and Its Relation to Aggressive Financial Reporting. Journal of Accounting Review, 84 (2), pp. 467-496.

Ghozali, I. (2018). Aplikasi Analisis Multivariate dengan Program IBM SPSS 25 (Edisi Sembilan). Semarang: Badan Penerbit Universitas Diponegoro.

Kandaka, \& Raisa, P. (2019). Pengaruh Komite audit, likuiditas, leverage, dan profitabilitas terhadap agresivitas pajak (studi empiris pada perusahaan industry barang konsumsi yang terdaftar di bursa efek Indonesia periode 2014-2017). Jurnal Akuntansi STIE Multi Data Palembang, pp. 1-19.

Kasmir. (2016). Analisis Laporan Keuangan. Jakarta: PT. Raja Grafindo Persada.

Kurniasih, T., \& Mari, M. R. S. (2013). Pengaruh Return On Assets, Leverage, Corporate Governance, Ukuran Perusahaan Dan Kompensasi Rugi Fiskal Pada Tax Avoidance. Buletin Studi Ekonomi, 18 (1), pp. 58-66.

Lin, J. W., Joon, S. Y., June, F. L. (2006). The Effect of Audit Committee Performance on Earnings Quality. Managerial Auditing Journal, 21 (9), pp. 921-933.

Nugroho, S. A., \& Amrie, F. (2017). Pengaruh Financial Distress, Real Earnings Management dan Corporate Governance Terhadap Tax Aggressiveness. Journal of Business Administration, 1 (2), pp. 163-182.

Ozkan, A. (2001). Determinants of Capital Structure andAdjustment to Long-run Target: Evidence from UK Company Panel Data. Journal of Business Finance and 
Accounting, 28, pp. 175-199.

Pohan, H. T. (2008). Pengaruh Good Corporate Governance, Rasio Tobin Q, Perataan Laba Terhadap Penghindaran Pajak pada Perusahaan Publik. Skripsi. Fakultas Ekonomi Universitas Trisakti Jakarta.

Putra, R. D., \& Elly, S. (2018). Pengaruh Manajemen laba, Leverage, dan Likuiditas Terhadap Agresivitas Pajak (Studi Pada Perusahaan Pertambangan yang Terdaftar di BEI Periode 2012-2016). E-Proceeding of Management, 5 (3), 3491-3499.

Putri, L. T. Y. (2014). Pengaruh Likuiditas, Manajemen Laba dan Corporate Governance Terhadap Agresivitas Pajak Perusahaan (Studi Empiris pada Perusahaan yang Terdaftar di BEI Periode 2008-2012). Artikel. Program Studi Akuntansi Fakultas Ekonomi, Universitas Negeri Padang.

Ratnawati, V., Nita, W., \& Arridho A. (2019). The Effect of Institutional Ownership, Board of Commissioners, Audit Committee on Tax Aggressiveness; Firm Size as a Moderating Variable. International Journal of Business and Economy, 1 (2), pp. 104115.

Republik Indonesia, (2015). Peraturan Otoritas Jasa Keuangan Nomor 55 /POJK.04/2015 Tentang Pembentukan dan Pedoman Pelaksanaan Kerja Komite Audit. Lembaran Negara Republik Indonesia Tahun 2015 Nomor 406. Jakarta.

Sekaran, U., \& Roger, B. (2017). Metode Penelitian untuk Bisnis: Pendekatan Pengembangan-Keahlian (Edisi 6 Buku 1). Cetakan Kedua. Jakarta: Salemba Empat.

Siahaan, F. O. P. (2005). Faktor-Faktor yang Mempengaruhi Perilaku Kepatuhan Tax Profesional dalam Pelaporan Pajak Badan Pada Perusahaan Industri Manufaktur di Surabaya. Disertasi. Program Pasca Sarjana Universitas Airlangga Surabaya.

Sukmawati, F., \& Cyntia, R. (2016). Pengaruh Likuiditas dan Leverage Terhadap Agresivitas Pajak Perusahaan Pada Perusahaan Industri Barang Konsumsi di Bursa Efek Indonesia Periode 2011-2014. Conference on Management and Behavioral Studies. Universitas Tarumanegara Jakarta, pp. 498-509.

Susanto, L., Yanti, \& Viriany. (2018). Faktor-Faktor yang Mempengaruhi Agresivitas Pajak. Jurnal Fakultas Ekonomi Universitas Tarumanagara, 23 (01), pp. 10-19.

Suyanto, K. D., \& Supramono. (2012). Pengaruh Likuiditas, Leverage, Komisaris Independen, dan Manajemen Laba Terhadap Agresivitas Pajak Perusahaan. Jurnal Keuangan dan Perbankan, 16 (2), pp. 167-177.

Tiaras, I., \& Henryanto, W. (2015). Pengaruh Likuiditas, Leverage, Manajemen Laba, Komisaris Independen dan Ukuran Perusahaan Terhadap Agresivitas Pajak. Jurnal Akuntansi, 19 (3), pp. 380-397.

Yanti, M. G. (2019). Analisis Pengaruh Corporate Social Responsibility, Komisaris Independen, dan Komite Audit Terhadap Agresivitas Pajak (Studi Empiris Pada Perusahaan Sektor Manufaktur yang Terdaftar di BEI Tahun 2017). Jurnal Kajian Ilmiah Akuntansi Fakultas Ekonomi UNTAN (KIAFE), 8 (2). 